\section{A century of wheat breeding in Brazil: the origin and inheritance of the Lr34 locus in wheat varieties released from 1922 to 2016}

\section{Márcia Soares Chaves', Gerarda Beatriz Pinto da Silva², Eduardo Caierão, Luiz Carlos Federizzi and José Antônio Martinelli ${ }^{2}$}

\begin{abstract}
Wheat breeding in Brazil began in 1919. A cross between the varieties Fronteira and Mentana gave rise to Frontana, the most popular ever released, being recommended for more than 40 years. Frontana played an important role as a source of resistance to leaf and stripe rust as well as resistance to preharvest sprouting. Possessing an early maturity cycle, it contributed to change the predominant varietal pattern at that time. The resistance gene Lr34 was first described in Frontana. The gene confers durable adult plant resistance to leaf rust and other biotrophic fungi. Because of its durability, stability across environments, haplotype diversity and wide geographical distribution, Lr34 is probably the most important single resistance gene in wheat. We evaluated 453 wheat varieties that have been released or recommended for cultivation in Brazil from 1922 to 2016 using KASPar markers to detect those varieties carrying the diagnostic mutations corresponding to the presence of the Lr34 resistance allele.
\end{abstract}

Keywords: Adult plant resistance, leaf rust, diagnostic molecular markers, KASPar.

\section{INTRODUCTION}

Wheat breeding in Brazil, which began in 1919, is completing a century in 2019 (Del Duca 1999, Sousa and Caierão 2014). The first lines were selected from among primitive wheats introduced by European immigrants in the $16^{\text {th }}$ century that displayed little adaptability to local growing conditions (Carmo 1911). In 1924, the first Brazilian wheat varieties - Polyssú and PG 1 (a Polyssú selection) - were released, and soon after were used intensively in crosses, giving rise to many descendants among cultivars in Brazil (Sousa 2003). In the 1920s, the Italian sib cultivars Mentana and Ardito, released in Italy in the early 1900s (Borghi 2001), were introduced and subsequently widely cultivated in Brazil; on account of their outstanding adaptability and disease resistance, they were used as parents in many local breeding programs (Sousa and Caierão 2014). In 1940 a cross between Fronteira and Mentana gave rise to Frontana (Del Duca 1999), the most popular variety ever released, now sowed across the country for more than 40 years (from 1940 to 1987) (Sousa and Caierão 2014). Frontana is the genotype with the greatest number of offspring among the commercial cultivars in Brazil, with 175 descendants in total. Frontana played an important role as a source of resistance to leaf and stripe rust, resistance to pre-harvest sprouting and as source of the early maturity cycle, inherited
Crop Breeding and Applied Biotechnology 20(2): e27952027, 2020 Brazilian Society of Plant Breeding. Printed in Brazil http://dx.doi.org/10.1590/198470332020v20n2a23

70332020v20n2a 23

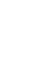


from Mentana, contributing to change the predominant varietal pattern at that time (Sousa and Caierão 2014). Frontana has been traced as the source of the Lr34 quantitative trait locus in a significant proportion of International Maize and Wheat Improvement Center (CIMMYT) cultivars as well as in Hard Red Spring Wheats from North America (Kolmer et al. 2008).

At present, $\operatorname{Lr34}$ is the best-known and studied adult plant resistance (APR) gene. It provides durable adult plant resistance to leaf rust (Puccinia triticina) as well as to other biotrophic fungi causing stripe rust (P. striiformis), stem rust (P. graminis tritici) and powdery mildew (Blumeria graminis) (Dyck 1977, German and Kolmer 1992, Bossolini et al. 2006, Spielmeyer et al. 2008). Co-segregation of $L r 34$ with other traits such as leaf tip necrosis ( $L t n)$, tolerance to barley yellow dwarf virus ( $B d v 1$ ) and spot blotch (Bipolaris sorokiniana) have been documented (Singh 1992a, b, Mclntosh 1992, Singh 1993, Joshi et al. 2004, Spielmeyer et al. 2005). Because of its durability (Johnson 1984), stability across environments (Lillemo et al. 2011), pleiotropy (Krattinger et al. 2009), haplotype diversity and wide geographical distribution (Dakouri et al. 2010, Dakouri et al. 2014), Lr34 is probably the most important single resistance gene in wheat.

Because the expression of the $L r 34$ multi-pathogen resistance locus is frequently masked by major $\mathrm{R}$ genes, the development of molecular markers has been a priority in many breeding programs (Bossolini et al. 2006, Lagudah et al. 2006, Kolmer et al. 2008, McCallum et al. 2008, Lagudah et al. 2009). The Lr34 gene has been isolated, sequenced and predicted to encode a pleiotropic drug resistance (PDR-like) ATP-binding cassette (ABC) transporter of 1,401 amino acids (Krattinger et al. 2009). This allowed the development of a group of perfect diagnostic markers (Lagudah et al. 2009), including the gene-specific marker calND11 (that detects the TCC indel in exon 11) the best diagnostic marker for marker-assisted selection of Lr34 due to its co-dominancy and robustness (Dakouri et al. 2010).

In a century of wheat breeding in Brazil, the joint efforts of many public and private research institutes resulted in the release of more than 540 varieties to farmers. Traits such as disease resistance, aluminum tolerance, cycle, plant height and architecture, as well as yield and technological quality were the focus of these breeding programs (Sousa and Caierão 2014). In this paper, we evaluated 453 wheat varieties released or recommended for cultivation in Brazil from 1922 to 2016 using KASPar markers to detect those varieties carrying the diagnostic mutation corresponding to the $\operatorname{Lr34}$ resistance allele. Based on the results of both DNA and pedigree analysis, we discuss the likely inheritance of this locus through generations of varieties released in Brazil, from the very beginning of breeding programs to the present day. We also present the reactions to leaf rust in adult plant stages of a group of varieties possessing the $\operatorname{Lr} 34$ resistance locus and discuss the stability of the rust reaction conferred across environments.

\section{MATERIAL AND METHODS}

\section{Plant material}

The germplasm collection comprised 453 hexaploid wheat genotypes that have been under cultivation in Brazil from 1922 to 2016 (Table S1). The majority (431) are improved varieties produced by local breeding programs. A few varieties were introductions from Italy (Ardito and Mentana), Uruguay (Centenário), Australia (Florence), Argentina (Buck Manantial), Mexico (Ciano 67, Inia 66, Jupateco 73, Pitic 62, Sonora 64, Tanori 71 and Anahuac 75), and Paraguay (Paraguay 214, Paraguay 281 and Itapua 5). Some landraces (Branco, Veadeiros, Sales, Camacrânia and Colonista) and varieties of unknown origin (Bandeirantes, General Vargas and Peladinho) that have been cultivated in Brazil were also analyzed. Seeds were provided by the Embrapa Wheat germplasm bank located in Passo Fundo, in the state of Rio Grande do Sul.

\section{DNA extraction and marker analysis}

Seeds from each accession were sown in commercial substrate and grown in a chamber under controlled temperature $\left(22 / 17^{\circ} \mathrm{C}\right.$, day/night) at $14 \mathrm{~h}$ daylength for 15 days. When the seedlings were at the two-leaf stage, leaf segments from one seedling per accession were cut and placed in $2 \mathrm{~mL}$ microtubes. Immediately after, the leaf samples were lyophilized for $48 \mathrm{~h}$. The dried tissue was macerated using Tissuelyser II (Qiagen) and the DNA was extracted according to the hexadecyltrimethylammonium bromide (CTAB) buffer protocol (Lefort and Douglas 1999). DNA concentrations were measured using a spectrophotometer (Thermo Scientific, USA) and normalized to about $100 \mathrm{ng}^{\mathrm{L}} \mathrm{L}^{-1}$. The DNA samples were placed in 96-well plates (PCR-96-FLT-C, Axygen) and sent to CenGen (Pty) Ltd., Worcester, South Africa, to be 
analyzed using the Kompetitive Allele Specific PCR (KASPar) marker. Trait-based KASP assays for the presence of Lr34/ Yr18/Sr57/Pm38 alleles (delTCC/delTCC) or (insTCC/insTCC) were run as previously described (Dreisigacker et al. 2016). The wheat variety Kariega was used as positive control and a no template control (NTC) was used as a negative control.

\section{Disease scoring}

The reaction to leaf rust of some wheat varieties was evaluated under field conditions, from 2006 to 2010 and in 2013. Because of the limited amount of seeds available at the Embrapa Wheat germplasm bank, only varieties with adequate number of seeds required to stablish field plots were included. Genetic stocks comprising near-isogenic lines and varieties from diverse origins known to possess the $L r 34$ gene were also evaluated for rust reaction. Highly susceptible Brazilian varieties were used as controls. Each genotype was sowed in approximately $1-\mathrm{m}$ rows, $20 \mathrm{~cm}$ apart, and 40 to 50 seeds were planted per plot. Spreader rows of the susceptible variety CD 104 were sowed perpendicular to plots and inoculated in early June with a mixture of races of $P$. triticina covering a wide range of the virulence occurring in Brazil. Races chosen were as follows: B25 (LCJRS), B27 (MBRMQ), B34 (MCJCN), B35 (MCHCN), B39 (CGTCQ), B43 (TDDQR), B48 (MCJMT), B49 (TFTCS), B50 (SPJRS), B51 (MFTCT), B52 (MFJMN), B54 (TFTCT), B55 (MFTMT), B56 (MFPCT), B57 (TDTMR), B58 (MDPMR) and B59 (MFTMT+). The mixture of isolates was suspended in Soltrol 170 oil and sprayed on the spreader rows in early October using a backpack sprayer. The severity and response rating for adult plant field resistance was based on the modified Cobb scale (Peterson et al. 1948). The host infection type was rated as $\mathrm{R}=$ resistant, very small uredinia with necrosis; $\mathrm{MR}=$ moderately resistant, small to moderate uredinia with necrosis; $\mathrm{MS}=$ moderately susceptible, small-to-moderate uredinia with chlorosis; and $\mathrm{S}=$ susceptible, large uredinia without necrosis or chlorosis (Roelfs et al. 1992). Leaf rust severity and resistance responses were recorded in mid-November when the susceptible control CD 104 had leaf rust severity of at least $80 \%$.

\section{RESULTS AND DISCUSSION}

In a century of wheat breeding in Brazil, more than 540 varieties were released to farmers. Because of the highly conducive environments, one of the major concerns addressed by these programs was the enhancement of levels of resistance to the common wheat diseases, including leaf rust. From the 453 accessions analyzed in this study, 117 (25.86\%) were found to carry the mutation (delTCC/delTCC) corresponding to the Lr34 leaf rust resistance allele (Table S1). A few lines presented a deletion in a single allele (delTCC/insTCC), and therefore the Lr34 locus was not confirmed to be present in these lines as a functional allele. The origin of the $L r 34$ resistance allele in Brazilian wheat varieties and its inheritance across decades over one century of wheat breeding is discussed below.

\section{The 1920 s and 1930 s}

Both Mentana and Ardito were found to carry the Lr34 gene using the diagnostic KASP markers, which is in accordance with previous results using other molecular markers (Kolmer et al. 2008, Dakouri et al. 2013). Mentana is the older recognized source of the Lr34 locus in South America (Kolmer et al. 2008); it was traced to be the most likely donor of the $L r 34$ gene to the majority of varieties detected to carry this gene, either directly or indirectly via Frontana (Figure 1). Branco and Veadeiros are the oldest Brazilian cultivars found to carry the Lr34 resistance gene (Table S1). Both are landraces and their pedigrees are unknown, and therefore the origin of the $L r 34$ gene in these varieties remains unclear. Minuano and Surpresa are also among the old cultivars possessing the Lr34 gene. Both were developed by Iwar Beckman from a cross between Polyssú and Alfredo Chaves 6-21. The cultivar Alfredo Chaves 6-21 is a selection from the landrace Turco (Sousa 1995), Polyssú is a landrace selected from undetermined Italian varieties in the early 1900s (Sousa 2003). Polyssú is the most likely donor of the Lr34 gene to Minuano and Surpresa because it carries the Ltn gene (causing leaf tip necrosis) which is a phenotypic marker associated with the gene Lr34 (Sousa and Barcellos 2000).

\section{The 1940s}

The first descendants from Mentana were released in the 1940s, with Frontana being the most important variety among them. Frontana is the most popular variety ever released in Brazil, being sowed across the country for 47 years (from 1940 to 1987). Frontana is the variety where the gene Lr34 was first described (Dick 1977). Subsequently, it was included in the group of genetic stocks used for the development of the diagnostic molecular markers (Lagudah et al. 
2009) used in our study. Here, we found that Frontana is the most likely source of the Lr34 gene of more than 50 wheat varieties released for cultivation in Brazil (Figure 1). In addition to Frontana, other varieties released in the 1940's were found to possess the Lr34 gene (Table S1), namely, Cincana, Floreana, Sales, and Lageadinho. Pitana descends from Mentana via Floreana; in our study, it was found to possess the $L r 34$ gene as well. Pitana also carries the $L r 13$ resistance gene, identified due to the linkage with the gene Ne2, producing the hybrid necrosis phenotype (Sousa 1999).

\section{The 1950s}

Of the four varieties released in this decade and found to carry the Lr34 gene using the diagnostic KASP markers, three are descendants from Frontana (Table S1, Figure 1), Veranópolis, Carazinho, and Fortaleza. Veranópolis and Carazinho also carry the Ne2 gene (Zeven 1973, Zeven 1981) and may carry the Lr13 resistance gene as well. Descending directly from Mentana, the cultivar BH 1146 was released in 1955 and remained under cultivation for 43 years (Sousa and Caierão 2014). In addition to possessing the Lr34 resistance allele, BH 1146 was widely used in the development of several other wheat genotypes, primarily due its tolerance to $\mathrm{Al}^{3+}$ (Sousa 1998). Our results are in accordance with previous reports in which the presence of the Lr34 gene was postulated in Veranópolis (Kaur et al. 2000, Kolmer et al 2008), Carazinho (McCallum et al. 2012), Fortaleza (Dakouri et al. 2013) and in BH 1146 (Sousa and Barcellos 2000, Kolmer et al. 2008, McIntosh et al. 2008).

\section{The 1960s}

The Lr34 gene present in the varieties released in the 1960s (Table S1) was probably inherited in one of four ways: 1) Directly or indirectly from Frontana (Figure 1): IAC 3 - descends directly from Frontana; Nova Prata and Cotiporã both descend from Veranópolis, released in 1950 and possessing the Lr34 gene, as previously discussed in this work. Cotiporã has been previously postulated to carry the Lr34 gene due to the presence of the Ltn gene associated with the leaf tip necrosis (Sousa and Barcellos 2000). Erexim most likely inherited Lr34 from Frontana via Colotana. Nobre probably inherited Lr34 from Frontana via Colotana or Yaktana 54. 2) Indirectly from Mentana (Figure 1): IAC 8 - Paraguaçu probably inherited Lr34 from Mentana via Heana, because Floreana descends directly from Mentana and was detected to possess the Lr34 gene in this study (Table S1). 3) Indirectly from Polyssú: Patriarca most likely inherited Lr34 from Minuano, as previously discussed in section The 1920s and 1930s. 4) From undetermined sources: Based on our results and on the pedigree analysis, the origin of the Lr34 gene could not be traced in the following varieties: IAS-C-45 Vila Velha, IAS-C-48 Guarapuava, and IAS 52.

\section{The 1970s}

This period was marked by the expansion of wheat acreage in Brazil and by the creation of many research centers for wheat improvement, including the National Wheat Research Center of Embrapa (Embrapa Wheat), located in Passo Fundo. During this decade, a long-lasting collaborative work between Embrapa Wheat and CIMMYT was established. Many varieties from Mexico and some varieties from Paraguay, Argentina, and Uruguay were introduced for cultivation in South Brazil, and these were used in crosses by the local breeding programs as well (Sousa and Caierão 2014). The Lr34 gene was detected in 19 varieties released in the 1970s (Table S1), where it was probably inherited in one of four ways: 1) Indirectly from Frontana (Figure 1): Encruzilhada most likely inherited Lr34 from Frontana via Fortaleza, released in 1957 and possessing Lr34 as discussed previously in this paper. C33 and Vacaria most likely inherited Lr34 from Frontana via Veranópolis, released in 1950, which descends directly from Frontana and was detected to possess the Lr34 gene, as discussed previously in this paper. Ciano 67 is one of the Mexican varieties introduced in Brazil in the 1970s and recommended for cultivation in 1976, which carries a combination of adult plant resistance genes to leaf rust and stem rust, as a Lr13, Lr34 and Sr2 complex (Mishra 1992). It was widely used in crosses by many breeding programs and a number of its descendants released in the 1980s were found to carry the Lr34 resistance allele (Figure 1), as will be further discussed in this paper. Ciano 67 most likely inherited Lr34 from Frontana via Chris, a North American variety derivative of Frontana and known to carry Lr34 (Kolmer et al. 2008). IAC 13-Lorena, released in 1977, descends directly from Ciano 67 and is assumed that they share the same source of the Lr34 gene. Glória probably inherited Lr34 from Frontana via Tezanos Pinto Criollo. Although we have not found any paper reporting that Tezanos Pinto Criollo possesses $L r 34$, Selkirk has been characterized as carrying the csLV34a allele and a no-Lr34 variety (Kolmer et al. 2008). Palotina and Nambu probably inherited Lr34 from Frontana via Tezanos Pintos Precoz, which descends directly from 
Frontana (GRIS 2019) and was detected to possess the Lr34 gene (Kolmer et al. 2008, Dakouri et al. 2013). The Mexican variety Jupateco 73 was very popular and achieved large acreage after its release in 1978 (Sousa and Caierão 2014). It has the same Lr34 resistance haplotype as Mentana and Frontana (the diagnostic 3-bp deletion in exon 11), suggesting the gene has a single origin in these varieties (Krattinger et al. 2009). 2) Directly or indirectly from Mentana (Figure 1): Regarding the variety Palotina, it may also be considered that Mentana could have been the donor of Lr34 via Nainari 60), known to carry the csLV34b allele, the functional form of Lr34 (Kolmer et al. 2008). The variety Confiança is a Nainari 60 reselection released in 1977, and we assume it inherited Lr34 from Mentana as discussed. Paraguay 281 is a Paraguayan variety descended from Mentana and recommended for cultivation in 1978. IAC 18-Xavantes descends from BH 1146, released in the 1950s, which was a very important variety in Brazil, as discussed previously in this paper. 3) Sources other than Frontana or Mentana: Some varieties have complex pedigrees, making the source of the Lr34 gene less than obvious. The Brazilian varieties LA 1434 and PAT 24 most likely inherited Lr34 from the Mexican varieties Yaqui 48 and Norteño 67, both possessing this resistance gene (Mishra 1992, Kolmer et al. 2008); nevertheless, the source is not clear considering their pedigrees (GRIS 2019). 4) From undetermined sources: Based on our results and on the pedigree analysis, the origin of the Lr34 gene could not be traced in the following varieties: S 76, Hulha Negra, Peladinho and LA 1549. Itapua 5 is a Paraguayan variety released for cultivation in Brazil in 1979. It possesses a complex pedigree in which Mentana, Ardito, and Frontana are present (GRIS 2019); nevertheless, none of its parental varieties are reported to carry the $\operatorname{Lr} 34$ gene.

\section{The 1980s}

This decade was considerably prolific, with 103 varieties released by local breeding program (Sousa and Caierão 2014). Thirty-five varieties were found to carry the Lr34 resistant allele (Table S1), the majority from breeding programs led by Embrapa (varieties Trigo BR), the Agronomic Institute of Campinas (varieties IAC), the Agronomic Institute of Paraná (varieties lapar) and the former Organization of Cooperatives of the State of Paraná (varieties Ocepar), currently the Cooperative for Technological and Economic Development (Coodetec). It is probable that the Lr34 gene detected in the varieties released in the 1980s had been inherited in one of three ways: 1) Indirectly from Frontana (Figure 1): Trigo BR 23 most likely inherited Lr34 from Frontana via Cotiporã, with Veranópolis being a direct descendant from Frontana that carries the Lr34 gene, as discussed previously in section The 1950s. The variety Trigo BR 23 was previously reported to carry the Ltn gene causing leaf tip necrosis, a phenotypic marker associated with the gene Lr34 (Sousa and Barcellos 2000). It also carries the Lr13 resistance gene, identified due to the linkage with the gene Ne2 producing the hybrid necrosis phenotype (Sousa 1999). Ciano 67 (Figure 1) and Tezanos Pinto Precoz, both descending from Frontana and possessing Lr34 (as previously discussed in section The 1970s) are most likely the donors of Lr34 to the following varieties: Pavão, Ocepar 7-Batuíra, Butuí, Trigo BR 11-Guarani, Ocepar 8-Macuco, Ocepar 10-Garça, Ocepar 11-Juriti, IAC 162-Tuiuiú, Trigo BR 17-Caiuá, Trigo BR 18-Terena, lapar 21-Taquari, lapar 30-Piratã, Trigo BR 29-Javaé, Ocepar 17, lapar 1-Mitacoré, El Pato, PAT 72247, lapar 17-Caeté, lapar 29-Cacatu, IAC 72-Tapajós, Trigo BR 33-Guará, and Ocepar 16. The pedigree analysis (Table S1) indicates that these two varieties and their descendants, including Bluebird, Aldan Sib, Siskin Sib, Tobari 66, Jaral Sib, and Bluejay (all possessing Lr34) participated in high frequency in the crosses originating the above-mentioned varieties. Otherwise, the CIMMYT-derived varieties Calidad and Penjamo 62 also participated in the cross originating Pavão, lapar 21-Taquari, and IAC 162-Tuiuiú, and therefore are likely donors of Lr34. 2) Indirectly from Mentana: Three of the above-mentioned varieties, namely Ocepar 7-Batuíra, IAC 162-Tuiuiú, and lapar 21-Taquari also could have inherited Lr34 from Kavkaz, a European winter wheat descending from Ardito (a sib cultivar to Mentana), reported to carry the csLV34b allele (Kolmer et al. 2008). Trigo BR 9-Cerrados and Serrano most likely inherited Lr34 from Mentana via BH 1146, released in the 1950s (Figure 1), as previously discussed. Ocepar 14 probably inherited Lr34 from Mentana via Almond. Ocepar 14 also has background from Cocoraque 75, a Mexican variety carrying the csLV34b allele (Kolmer et al. 2008) released for cultivation in Brazil in 1981 (Sousa and Caierão 2014). 3) From undetermined sources: Based on our results and on the pedigree analysis, the origin of the Lr34 gene could not be traced in the following varieties: lapar 3-Aracatu, Jandaia, lapar 6-Tapejara, IAC 21-Iguaçu, Minuano 82, IAC 23-Tocantins, RS 1-Fênix, RS 4-Ibiraiaras, IAC 27-Pantaneiro, and Trigo BR 35. Trigo BR 35 has been previously postulated to carry a combination of $L r 13+L r 34$ resistance genes, due to the presence of the $L t n$ and $N e 2$ genes, causing leaf tip necrosis and the hybrid necrosis phenotype, respectively (Sousa 1999, Sousa and Barcellos 2000).

\section{The 1990s}




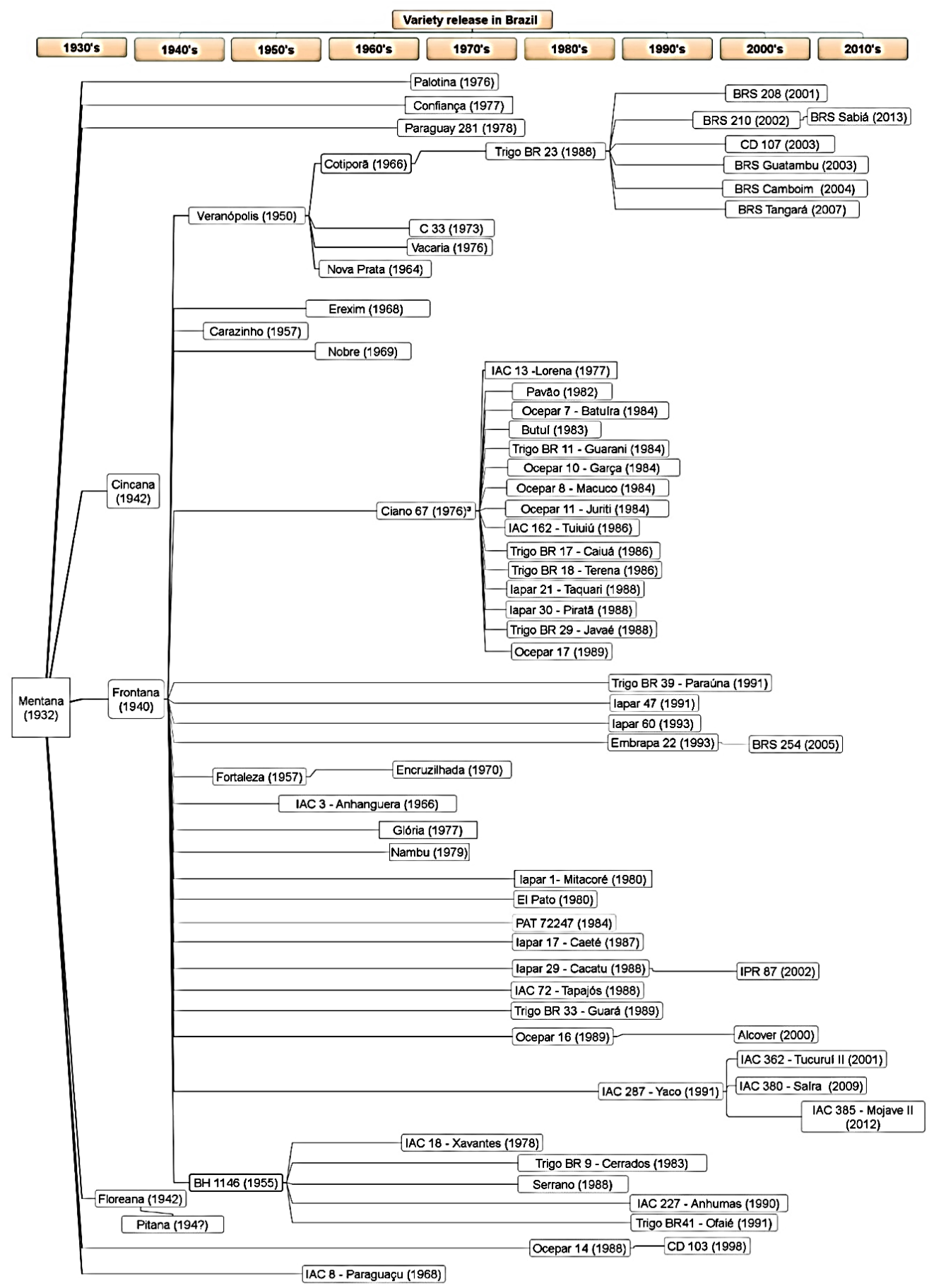

Figure 1. Likely origin and inheritance of the Lr34 resistance allele in wheat varieties released in Brazil from 1922 to 2016. 
The 1990s were equally prolific regarding the number of varieties released (Sousa and Caierão 2014). However, there was decrease in the number of varieties detected to carry the Lr34 gene (11 varieties, Table S1), probably inherited in one of three ways: 1) Indirectly from Frontana (Figure 1): Trigo BR 39-Paraúma, lapar 47, lapar 60 , and IAC 287-Yaco have pedigrees that trace back to the cultivars Ciano 67, Chris, and Tezanos Pintos Precoz, which were important sources of the $\operatorname{Lr34}$ gene in the varieties released in the 1970s, as previously discussed in this paper. The Mexican variety Jupateco 73 (see section The 1970s) is the most likely donor of Lr34 to Embrapa 22 and is possibly the source of Lr34 in lapar 60. IAC 287 may also have inherited Lr34 from Cocoraque 75, which also carries the csLV34b allele (Kolmer et al. 2008) as previously discussed in section The 1980s. 2) Indirectly from Mentana: The above-mentioned variety lapar 47, alternatively, may have inherited Lr34 from Mentana via Kavkaz, as previously discussed in section The 1980s. IAC 227-Anhumas and Trigo BR 41-Ofaé most likely inherited Lr34 from Mentana via BH 1146 (Figure 1), as previously discussed in the section The 1950s. CD 103 probably inherited Lr34 from Ocepar 14, released in 1988, which pedigree has been discussed in the corresponding section. 3) From undetermined sources: Based on our results and on the pedigree analysis, the origin of the Lr34 gene could not be traced in three varieties: RS 8-Westphalen, Manitoba 97, and lapar 40-Mirim. Kolmer et al. (2008) included IAC 5-Maringá in the group of varieties possessing the csLV34b allele, and then this variety could be considered as the donor of Lr34 to lapar 40. However, in our study, IAC 5 was not found to possess the diagnostic deletion that unambiguously identify the presence of $\operatorname{Lr} 34$.

\section{The 2000s}

We tested 87 varieties released for cultivation between 2000 and 2009. Of these, 19 were found to possess the Lr34 allele (Table S1) all of which were probably inherited in one of three ways: 1) Indirectly from Frontana (Figure 1): The variety Trigo BR 23 was released in the 1980s (please refer to this section for pedigree analysis) and was widely cultivated in the 1990s (Sousa and Caierão 2014). It is the most likely donor of the Lr34 gene to BRS 208, BRS 210, CD 107 BRS Guatambu, BRS Camboim, and BRS Tangará. Otherwise, CD 107 may have inherited Lr34 from Cocoraque 75 or from Trigo BR 35 (see section The 1980s). Regarding the variety BRS Camboim, an alternative origin of the Lr34 allele may be the Argentinian variety Klein Cartucho, reported to carry the $c s L V 34 b$ allele (Kolmer et al. 2008), presumably inherited from Penjamo 62, Jupateco 73) or Calidad. The varieties BRS 254, IPR 87, Alcover, IAC 362-Tucuruí II and IAC 380-Saíra are descendants from varieties released in the 1980s and 1990s (Embrapa 22, lapar 29, Ocepar 16 and IAC 287-Yaco) which have pedigrees that trace back to Lr34-carrying varieties Tezanos Pintos Precoz, Jupateco 73, Ciano 67 and Chris (see section The 1970s). 2) Indirectly from Mentana: BRS 296 probably inherited Lr34 from the Australian variety Cook, a derivative of WW15 = Anza (Mclntosh et al. 1995). WW15 and Anza served as key donors of Lr34 in the Australian wheat gene pool and were originated from the CIMMYT variety Lerma Rojo, which is derivative of crosses with Mentana (GRIS 2019) and was found to carry the csVL34b allele (Kolmer et al. 2008). 3) From undetermined sources: Based on our results and on the pedigree analysis, the origin of the $L r 34$ gene could not be traced in the following varieties: CD 106, IAC 364-Tucuruí III, CD 109, BRS Camboatá, BRS Reponte, BRS Guamirim and IPR 129.

\section{The 2010s}

Despite the great progress of wheat breeding observed in the current decade, when 62 varieties were released by 11 public and private companies, there was a steep decrease in the number of varieties carrying the $L r 34$ (only 7 ), the least since the landmark represented by Fontana. This reduction may be because the Lr34-mediated resistance imposes high energetic demands that lead to the induction of multiple metabolic responses to support cellular energy requirements (Bolton et al. 2008). The energetic cost of the resistance provided by the Lr34 gene may probably affect the yield so as to negatively affect the selection of lines carrying the Lr34 locus. Furthermore, the selection pressure for cultivars with better grain quality could have decreased the intensity of selection for resistance to rust. In the varieties released in the 2010s in which the Lr34 gene was found, inheritance may have occurred in one of two ways: 1) Indirectly from Frontana (Figure 1): BRS Sabiá and IAC 385-Mojave descend from varieties BRS 210 (released in 1988) and IAC 287Yaco (released in 1991), respectively. In our study, both BRS 210 and IAC 287-Yaco were found to carry the Lr34 gene with origin traced back to Frontana, as discussed in the respective sections (see sections The 1980s and The 1990s). 2) From undetermined sources: Based on our results and on the pedigree analysis, the origin of the Lr34 gene could not be traced in the following varieties: TBIO Seleto, LG Prisma, and FPS Certero. Although BRS Marcante and LG Supra most probably inherited Lr34 from BRS Guamirim (released in 2004), nevertheless, the source of the resistant allele in this variety could not be traced in our work. 


\section{Adult plant field resistance}

The resistance phenotype of $L r 34$ is characterized by an increased latent period, reduced infection frequency, smaller uredinia, and a decreasing gradient of uredinia from leaf base to tip (Bolton et al. 2008). Genetic analysis of Frontana and many CIMMYT wheats showing high levels of partial resistance to leaf rust worldwide indicates that this adult plant resistance is based on the additive interaction of $L r 34$ and two or three additional slow rusting genes (Singh and Rajaram 1992). In Mexico, leaf rust severity on most cultivars can be related to the number of slow rusting genes they carry. While susceptible cultivars can show $100 \%$ of leaf rust severity, cultivars carrying $L r 34$ alone can display $50 \%$ of rust severity; cultivars with Lr34 plus one or two minor genes display up to $30 \%$ of severity; and cultivars with $\operatorname{Lr} 34$ and two or three additional genes show a stable response across environments, with final leaf rust ratings lower than $10 \%$ (Singh and Rajaram 2002). In Brazil, wheat-producing areas are in environments very conducive to leaf rust epidemics and prevalent races change dramatically over time according to the resistance genes present in the commercial cultivars (German et al. 2007). In our work, the susceptible varieties displayed high levels of severity, mostly $80 \%$ to $100 \%$, while the Lr34-carrying genotypes (Brazilian varieties and Lr34-genetic stocks) showed reactions compatible with the phenotypes described above (Table 1). Among the varieties, Pitana and BH 1146 likely possess the Lr34 gene alone, because the leaf rust reaction ranged from $15 \%$ to $50 \%$ of severity with susceptible infection types. These varieties have been reported to carry additional $L r$ genes (Table 1); however, they are not effective against the prevalent races occurring in the Southern Cone of America (German et al. 2011). The field reaction of Cincana, Patriarca, Minuano 82, Trigo BR, 18-Terena, Trigo BR 23, Trigo BR 35, Embrapa 22, CD 103, BRS 208, IPR 87, BRS Guatambu, BRS Camboatá, BRS 254, and IAC 385-Mojave ranged from 5 S to 30SMSMR (Table 1), compatible with the presence of Lr34 associated with one or two additional resistance genes. The field reaction of RS 8-Westphalen, BRS 210, BRS Guamirim, BRS Tangará, BRS 296, BRS Marcante and BRS Sabiá ranged across years from $1 S$ to 20MR, suggesting that, in these varieties, the resistance probably is due to the presence of $L r 34$ and two, three, or more additional genes. The Lr34-carrying genetic stocks displayed low levels of disease severity (Table 1) ranging from 3 S to 20SMS in RL 6050, RL 6114, RL 6058, Chris,

Table 1. Adult plant rust reaction under field conditions of Brazilian Lr34-carrying wheat varieties, Lr34-carrying genetic stocks and susceptible varieties

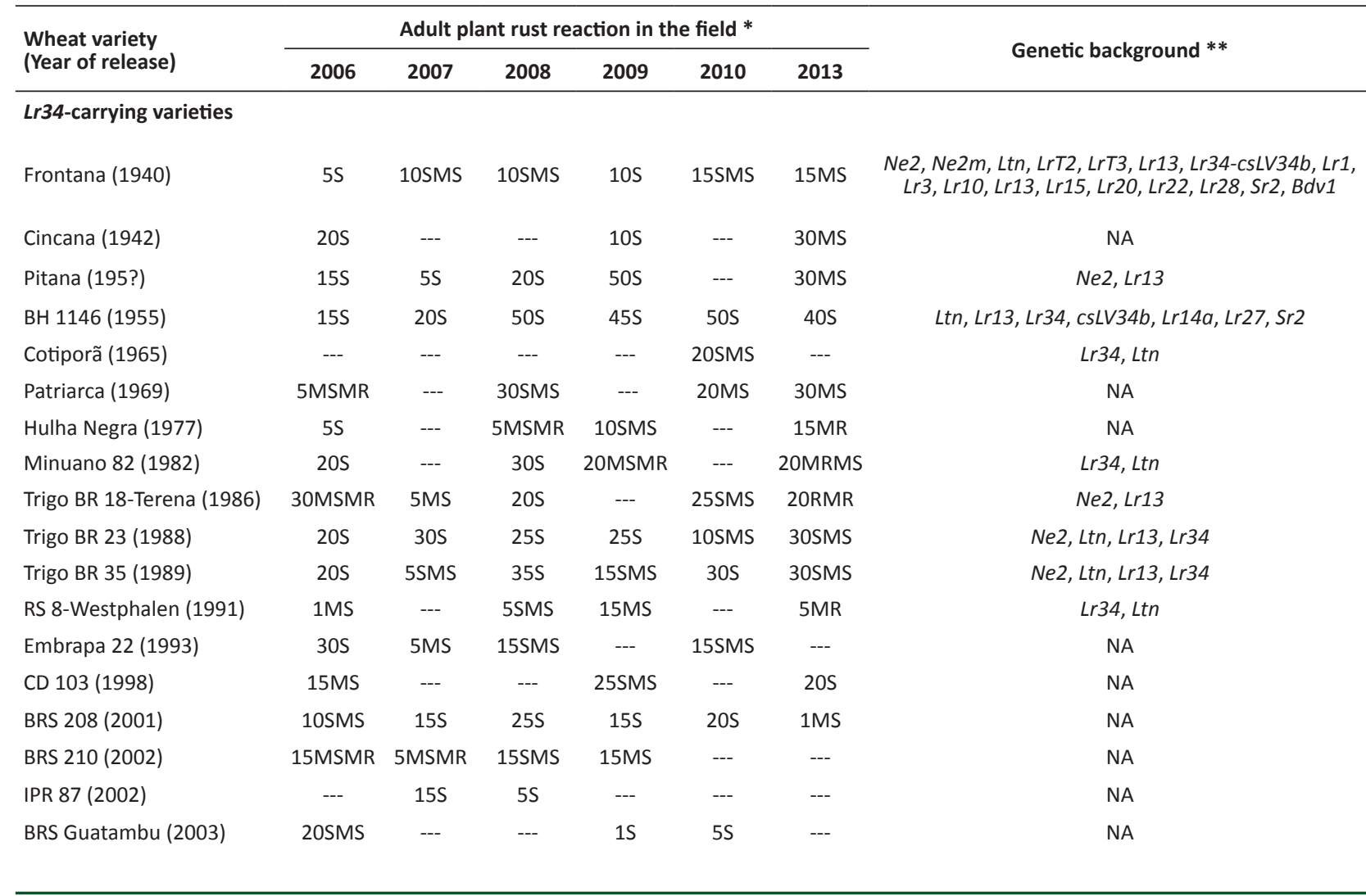




$\begin{array}{lccccccc}\text { BRS Camboatá (2003) } & --- & 10 M S & 25 S & --- & 25 S & --- & \text { NA } \\ \text { BRS Guamirim (2004) } & 5 S M S & 1 S M S & 15 S & 5 M S M R & 5 S & --- & \text { NA } \\ \text { BRS 254 (2005) } & 10 S & 5 M S & 15 S M S & 25 M S M R & --- & --- & \text { NA } \\ \text { IPR 129 (2006) } & 30 S & 1 M S & 30 S & --- & --- & --- & \text { NA } \\ \text { BRS Tangará (2007) } & 10 \mathrm{MSMR}^{1} & 5 S & 10 S & 15 M S M R & 5 S & --- & \text { NA } \\ \text { BRS 296 (2009) } & 5 \text { MSS }^{2} & \text { TMS }^{2} & --- & 8 M S & 1 S & 15 M S & \text { NA } \\ \text { BRS Marcante (2012) } & --- & --- & --- & --- & 3 M^{3} & 20 M R & \text { NA } \\ \text { IAC 385-Mojave (2012) } & --- & --- & --- & --- & --- & 30 S M S & \text { NA }\end{array}$

\begin{tabular}{|c|c|c|c|c|c|c|c|}
\hline $\begin{array}{l}\text { Wheat variety } \\
\text { (Year of release) }\end{array}$ & \multicolumn{6}{|c|}{ Adult plant rust reaction in the field * } & Genetic background ** \\
\hline \multicolumn{8}{|c|}{ Lr34-carrying genetic stocks and genotypes } \\
\hline RL 6050 & $10 \mathrm{~S}$ & --- & 20SMS & 10SMS & --- & --- & $\operatorname{Lr} 13+\operatorname{Lr} 34$ \\
\hline RL 6114 & 10SMS & --- & $10 \mathrm{~S}$ & $10 \mathrm{MS}$ & --- & --- & $\operatorname{Lr} 13+\operatorname{Lr} 34$ \\
\hline RL 6058 & 10SMS & --- & $10 \mathrm{~S}$ & $10 \mathrm{MS}$ & & & Lr34 \\
\hline Chris & $5 \mathrm{MS}$ & --- & --- & $10 \mathrm{~S}$ & --- & --- & Lr10, Lr13, Lr27, Lr34-csLV34b \\
\hline Coker 797 & $15 \mathrm{R} / 5 \mathrm{~S}$ & --- & --- & $15 R$ & --- & --- & Lr10, Lr11, Lr13, Lr14a, Lr34, Lr18+ \\
\hline Buck Buck & 15MRMS & --- & $5 \mathrm{MS}$ & $15 \mathrm{MSMR}$ & --- & --- & $\operatorname{Lr} 13, \operatorname{Lr} 16$ \\
\hline Era & $5 S$ & --- & --- & $60 \mathrm{~S}$ & --- & --- & Ltn, Sr2, Lr13, Lr34-csLV34b, Lr10, Lr12, Lr23, Lr27 \\
\hline Pampa INTA & 15MRMS & --- & $15 S$ & $10 \mathrm{MS}$ & --- & & $R h t 2, \operatorname{Lr} 28, \operatorname{Lr} 34$ \\
\hline Parula & $5 \mathrm{MS}$ & --- & $3 S$ & --- & --- & --- & $\begin{array}{l}\text { Ltn1, Ltn2, Lr3b, Lr13, Lr34/Yr18/Sr57/Pm38-csLV34b } \\
\text { Lr46/Yr29/Sr58/Pm39, Lr68, T1BL.1RS, Bdv1, Sr2/Yr30 }\end{array}$ \\
\hline Tonichi 81 & $5 S M S$ & --- & $15 \mathrm{MS}$ & 10SMS & --- & --- & $\begin{array}{c}\text { Ne2, Ltn, } \operatorname{Lr12}, \operatorname{Lr} 13, \operatorname{Lr} 34, \operatorname{cs} L V 34 b, \operatorname{Lr} 1, \operatorname{Lr} 10, \operatorname{Lr} 14 a \\
\operatorname{Lr} 27, \operatorname{Lr} 31, \operatorname{Lr} 49, \operatorname{Sr} 2, B d v 1\end{array}$ \\
\hline \multicolumn{8}{|c|}{ Susceptible varieties (not carrying Lr34) } \\
\hline Anahuac 75 (1981) & $80 S$ & $20 \mathrm{MS}$ & $25 S$ & $80 S$ & $100 \mathrm{~S}$ & $50 \mathrm{~S}$ & NA \\
\hline OR 1 (1996) & $80 \mathrm{~S}$ & $80 S$ & $45 S$ & $100 \mathrm{~S}$ & $100 \mathrm{~S}$ & --- & NA \\
\hline Safira (2004) & $50 S$ & $25 S$ & $30 \mathrm{~S}$ & $70 S$ & $90 \mathrm{~S}$ & --- & NA \\
\hline Fundacep Nova Era (2004) & $70 \mathrm{~S}$ & $25 S$ & $20 \mathrm{~S}$ & $90 \mathrm{~S}$ & $70 \mathrm{~S}$ & --- & NA \\
\hline Fundacep 52 (2005) & $20 \mathrm{MS}$ & $70 \mathrm{~S}$ & $50 \mathrm{~S}$ & --- & $90 \mathrm{~S}$ & $40 S$ & NA \\
\hline Abalone (2006) & $20 S$ & $50 \mathrm{~S}$ & $50 \mathrm{~S}$ & -- & $90 \mathrm{~S}$ & $80 \mathrm{~S}$ & NA \\
\hline Quartzo (2007) & --- & --- & $60 \mathrm{~S}$ & $70 \mathrm{~S}$ & $75 S$ & $80 \mathrm{~S}$ & NA \\
\hline
\end{tabular}

* Rust reaction scored as the severity (percentage of leaf area affected by leaf rust) and the infection type: $\mathrm{R}=$ resistant, very small uredinia with necrosis; $\mathrm{MR}=$ moderately resistant, small to moderate uredinia with necrosis; MS = moderately susceptible, small to moderate uredinia with chlorosis; and S = susceptible, large uredinia without necrosis or chlorosis; $T=$ traces of infection, meaning less than $1 \%$ of the leaf area affected by leaf rust (Roelfs et al. 1992). ${ }^{* *}$ According to the Genetic Resources Information System for Wheat and Triticale (GRIS) http://wheatpedigree.net/. NA: Not available. Tested as advanced lines: ${ }^{1}$ PF 003295-A/B, ${ }^{2}$ PF $990283,{ }^{3}$ PF 080310, ${ }^{4}$ IWT 08111 


\section{MS Chaves et al.}

Cocoraque 75, Coker 797, Buck Buck, Esmeralda 86, Glenlea, Pampa INTA, Parula and Tonichi 81 . Esmeralda 86 and Glenlea showed maximum leaf rust ratings of 25SMS and 35S, respectively. The results obtained in this work confirm the presence of the $L r 34$ resistant allele in many Brazilian wheat varieties, which has been mostly inherited directly and indirectly from Mentana and Frontana and the genetic variability observed in the wheat germplasm in Brazil is equally distributed across the local wheat breeding programs as described by Scherlosky et al. (2018). It can be noticed that this important locus has been maintained over time, even though unconsciously during the cycles of phenotypic selection. Additionally, our results confirm the high level and stability of the partial resistance conferred by $L$ r34 across years under a very conducive environment, and across a wide diversity of genetic backgrounds, as reported by Lillemo et al. (2011).

\section{ACKNOWLEDGEMENTS}

The authors thank the Brazilian National Council for Scientific Research and Development (Conselho Nacional de Desenvolvimento Científico e Tecnológico, CNPq) for the financial support. Supplementary Table S1 is available with Luiz Carlos Federizzi (federizi@ufrgs.br).

\section{REFERENCES}

Bolton MD, Kolmer JA, Xu WW and Garvin DF (2008) Lr34-mediated leaf rust resistance in wheat: Transcript profiling reveals a high energetic demand supported by transient recruitment of multiple metabolic pathways. Molecular Plant-Microbe Interactions 21: 1515-1527.

Borghi B (2001) Italian wheat pool. In Bonjean AP and Angus WJ (Eds) The world wheat book: A history of wheat breeding. Intercept, London, p. 289-309.

Bossolini E, Krattinger SG and Keller B (2006) Development of SSR markers specific for the $L r 34$ resistance region of wheat using sequence information from rice and Aegilops tauschii. Theorethical and Applied Genetics 113: 1049-1062.

Carmo AG (1911) O problema nacional da produção do trigo. Divulgador Brasileiro, Rio de Janeiro, 324p.

Dakouri A, Mccallum BD and Cloutier S (2014) Haplotype diversity and evolutionary history of the Lr34 locus of wheat. Molecular Breeding 33: 639-655.

Dakouri A, McCallum BD, Radovanovic N and Cloutier S (2013) Molecular and phenotypic characterization of seedling and adult plant leaf rust resistance in a world wheat collection. Molecular Breeding 32: 663-677.

Dakouri A, McCallum BD, Walichnowski AZ and Cloutier S (2010) Finemapping of the leaf rust $L r 34$ locus in Triticum aestivum (L.) and characterization of large germplasm collections support the $A B C$ transporter as essential for gene function. Theorethical and Applied Genetics 121: 373-384.

Del Duca (1999) Geneticista Iwar Beckman. In Cunha GR (Org) Trigo 500 anos no Brasil. Embrapa Trigo, Passo Fundo, 110p.

Dreisigacker S, Sehgal D, Reyes Jaimez AE, Luna Garrido B, Muñoz Zavala S, Núñez Ríos C, Mollins J and Mall S (2016) CIMMYT wheat molecular genetics: laboratory protocols and applications to wheat breeding. CIMMYT, D.F., México, 142p. Available at <https://repository.cimmyt. $\mathrm{org} /$ bitstream/handle/10883/18822/58119. pdf? sequence=1 $>$. Accessed on February 5, 2020.

Dyck PL (1977) Genetics of leaf rust reaction in three introductions of common wheat. Canadian Journal of Genetics and Cytology 19: 711-716.

German S, Barcellos A, Chaves M, Kohli M, Campos P and Viedma L (2007) The situation of common wheat rusts in the southern cone of America and perspectives for control. Australian Journal of Agricultural Research 58: 620-630.

German S, Campos P, Chaves M, Madariaga R and Kohli M (2011) Challenges in controlling leaf rust in the Southern Cone region of South America. In Proceedings of Borlaug Global Rust Initiative (BGRI) technical workshop. BGRI, Saint Paul, p. 14-23.

German SE and Kolmer JA (1992) Effect of gene Lr34 in the enhancement of resistance to leaf rust of wheat. Theoretical and Applied Genetics 84: 97-105.

GRIS - Genetic Resources Information System for Wheat and Triticale (2019). Available at: < http://wheatpedigree.net/sort/ renderPedigree/27849 >. Accessed on February 18, 2020.

Johnson R (1984) A critical analysis of durable resistance. Annual Review of Phytopathology 22: 309-30.

Joshi AK, Chand R, Kumar S and Singh RP (2004) Leaf tip necrosis: a phenotypic marker associated with resistance to spot blotch disease in wheat. Crop Science 44: 792-796.

Kaur M, Saini RG and Preet K (2000) Adult plant leaf rust resistance from 111 wheat (Triticum aestivum L.) cultivars. Euphytica 113: 235-243.

Kolmer JA, Singh RP, Garvin DF, Viccars L, William HM, Huerta-Espino J, Ogbonnaya FC, Roman H, Orford S, Bariana HS and Lagudah ES (2008) Analysis of the $L r 34 / Y r 18$ rust resistance region in wheat germplasm. Crop Science 48: 1841-1852.

Krattinger SG, Lagudah ES, Spielmeyer W, Singh RP, Huerta-Espino J, McFadden H, Bossolini E, Selter LL and Keller B (2009) A putative ABC transporter confers durable resistance to multiple fungal pathogens in wheat. Science 323: 1360-1363.

Lagudah ES, Krattinger SG, Herrera-Foessel S, Singh RP, Huerta-Espino J, Spielmeyer W, Brown-Guedira G, Selter LL and Keller B (2009) Genespecific markers for the wheat gene $L r 34 / Y r 18 / P m 38$ which confers resistance to multiple fungal pathogens. Theoretical and Applied 
Genetics 119: 889-898.

Lagudah ES, McFadden H, Singh RP, Huerta-Espino J, Bariana HS and Spielmeyer W (2006) Molecular genetic characterization of the Lr34/ Yr18 slow rusting resistance gene region in wheat. Theoretical and Applied Genetics 114: 21-30.

Lefort F and Douglas GC (1999) An efficient micro-method of DNA isolation from mature leaves of four hardwood tree species Acer, Fraxinus, Prunus and Quercus. Annals of Forest Science 56: 259-263.

Lillemo $M$, Singh RP, William M, Herrera-Foessel SA, Huerta-Espino J, Germán S, Campos P, Chaves M, Madriaga R, Xia X, Liang S, Liu D, Li $Z$ and Lagudah $E$ (2011) Multiple rust resistance and gene additivity in wheat: lessons from multi-location case studies in the cultivars Parula and Saar. Oral presentation of Borlaug Global Rust Initiative (BGRI) technical workshop. BGRI, St. Paul, p. 111-120.

McCallum BD, Humphreys DG, Somers DJ, Dakouri A and Cloutier S (2012) Allelic variation for the rust resistance gene Lr34/Yr18 in Canadian wheat cultivars. Euphytica 183: 261-274.

McCallum BD, Somers DJ, Humphreys DG and Cloutier S (2008) Molecular marker analysis of Lr34 in Canada Western Red spring wheat cultivars. In Appels R, Eastwood, Lagudah E, Langridge, Mackay, McIntyre L and Sharp (Eds) Proceedings of the $11^{\text {th }}$ international wheat genetics symposium. University Press, Sydney, p. 1-3.

McIntosh RA (1992) Close genetic linkage of genes conferring adult plant resistance to leaf rust and stripe rust in wheat. Plant Pathology 41: 523-527.

McIntosh RA, Devos KM, Dubcovsky J, Rogers WJ, Morris CF, Appels R, Somers DJ and Anderson OA (2008) Catalogue of gene symbols for wheat. In Appels R, Eastwood, Lagudah E, Langridge, Mackay, McIntyre $L$ and Sharp (Eds) The 11th international wheat genetics symposium proceedings. Sydney university press, Brisbane, Supplement, $15 \mathrm{p}$.

Mclntosh RA, Wellings CR and Park RF (1995) Wheat rust. An atlas of resistance genes. CSIRO, Australia, 200p.

Mishra AN (1992) Sources of combined adult plant resistance to stem rust and leaf rust of wheat probably derided from $\mathrm{Sr} 2$ complex and Lr34 complex. Annual Wheat Newsletter 38: 135-138.

Peterson RF, Campbell AB and Hannah AE (1948) A diagramatic scale for estimating rust intensity of leaves and stem of cereals. Canadian Journal of Research 26: 496-500.

Roelfs AP, Singh RP and Saari EE (1992) Rust diseases of wheat: Concepts and methods of disease management. CIMMYT, Mexico, 81p.

Scherlosky A, Marchioro VS, Franco FA, Braccini AL and Schuster I (2018) Genetic variability of Brazilian wheat germplasm obtained by highdensity SNP genotyping. Crop Breeding and Applied Biotechnology 18: 399-408.
Singh RP (1992a) Genetic association of leaf rust resistance gene Lr34 with adult plant resistance to stripe rust in bread wheat. Phytopathology 82: 835-838.

Singh RP (1992b) Association between gene Lr34 for leaf rust resistance and leaf tip necrosis in wheat. Crop Science 32: 874-878.

Singh RP (1993) Genetic association of gene Bdv1 for tolerance to barley yellow dwarf virus with genes $L r 34$ and $Y r 18$ for adult plant resistance to rusts in bread wheat. Plant Disease 77: 1103-1106.

Singh RP and Rajaram S (1992) Genetics of adult-plant resistance to leaf rust in 'Frontana' and three CIMMYT wheats. Genome 35: 24-31.

Singh RP and Rajaram S (2002) Breeding for disease resistance in wheat. In BC Curtis, S Rajaram and H Gomez Macpherson (eds) Bread wheat improvement and production. Plant Production and Protection Series. FAO, Rome, p. 141-156.

Sousa CNA (1995) Cultivares de trigo no Brasil: I - Cultivares disponíveis antes de 1950. Embrapa CNPT, Passo Fundo, 34p. (Documentos 24).

Sousa CNA (1998) Classification of Brazilian wheat cultivars for aluminium toxicity in acid soils. Plant Breeding 117: 217-221.

Sousa CNA (1999) Survey on hybrid necrosis in Brazilian wheat cultivars/ Items from Brazil. Annual Wheat Newsletter 45: 40-41.

Sousa CNA (2003) Jorge Polysú e o desenvolvimento da cultivar de trigo Polyssú. Embrapa Trigo, Passo Fundo, 28p. (Documentos 41).

Sousa CNA and Barcellos AL (2000) Evaluation of leaf-tip necrosis in Brazilian wheat genotypes/Items from Brazil. Annual Wheat Newsletter 46: 28-32.

Sousa CNA and Caierão E (2014) Cultivares de trigo indicadas para cultivo no Brasil e instituições criadoras - 1922 a 2014. Embrapa, Brasília, 200p.

Spielmeyer W, McIntosh RA, Kolmer J and Lagudah ES (2005) Powdery mildew resistance and $L r 34 / Y r 18$ genes for durable resistance to leaf and stripe rust cosegregate at a locus on the short arm of chromosome 7D of wheat. Theoretical and Applied Genetics 111: 731-735.

Spielmeyer W, Singh RP, McFadden H, Wellings CR, Huerta-Espino J, Kong $X$, Appels R and Lagudah ES (2008) Fine scale genetic and physical mapping using interstitial deletion mutants of $L r 34 / Y r 18$ : a disease resistance locus effective against multiple pathogens in wheat. Theorical and Applied Genetics 116: 481-490.

Zeven AC (1973) Sixth supplementary list of wheat varieties classified according to their genotype for hybrid necrosis and geographical distribution of Ne-genes. Euphytica 22: 618-632.

Zeven AC (1981) Eighth supplementary list of wheat varieties classified according to their genotype for hybrid necrosis. Euphytica 30: 521-539.

(cc) EY This is an Open Access article distributed under the terms of the Creative Commons Attribution License, which permits unrestricted use, distribution, and reproduction in any medium, provided the original work is properly cited. 